\title{
Explaining Education-to-Work Transitions: Thinking Backwards, Situating Agency and Comparing Countries
}

\author{
Ken Roberts ${ }^{1}$ \\ ${ }^{1}$ University of Liverpool, England \\ Correspondence: Ken Roberts, Address. University of Liverpool, England. E-mail: bert@liverpool.ac.uk \\ Received: January 4, 2018 Accepted: January 19, 2018 Online Published: February 3, 2018 \\ doi:10.5539/res.v10n1p72 URL: https://doi.org/10.5539/res.v10n1p72
}

\begin{abstract}
This paper argues that explanations must start at the end of young people's education-to-work transitions, with employers' recruitment behaviour and preferences, which then govern the content of and recruitment to preceding education and training. Young people themselves exercise agency: this propels their careers forward biographically, but necessarily consolidates opportunity structures (variously called routes, pathways or trajectories) that have been pre-built from above. It is also argued that ultimately the transition regime in every country, and sometimes in each region and business sector, needs to be treated as a unique case study. However, these regimes can be divided into recognisable types which are most easily identified by starting in an economy and its labour markets. Finally, it follows that attempts which start in earlier life, prior to young people entering the labour market, to modify links between social origins and occupational destinations will invariably fail. Effective interventions can be envisaged only by starting at the end of young people's transitions, then thinking backwards.
\end{abstract}

Keywords: education, employment, labour markets, training, transitions, youth

\section{Introduction}

Education-to-work is just one among many transitions that are normally accomplished during youth. This life stage involves a comprehensive set of transitions. These include family relationships, housing, political and welfare rights, treatment by police and courts, and access to consumer markets. However, the education-to-work transition is pivotal. It influences how and when other life stage transitions are made, and as with all other youth life stage transitions, the outcomes are likely to have lifelong consequences. Sometimes occupational careers are disrupted by economic and technological changes. Marriages sometimes fail. These disruptions, when they occur, are major life events, comparable to the outcomes of youth life stage transitions which are different in scale because they affect entire populations.

The education-to-work transition is certainly not under-researched. It has been a leading issue in youth studies ever since youth unemployment began to spread from country-to-country in Western Europe in the 1970s and 80s. Quantitative researchers have examined the links between social origins (usually indicated by family social class or socio-economic status and attainments in compulsory education) and adult destinations in the labour force. This simple origins-destinations model has been expanded partly, but not wholly, due to the decline in youth employment and the spread of unemployment, and the expansion of old and the creation of new forms of post-compulsory and training. The youth life stage has thereby lengthened, and researchers have explored the intervening routes or pathways through post-compulsory education, training, part-time and temporary jobs, and other precarious steps towards employment that will support an adult life style (see, for example, Andres and Adamuti-Trache, 2008; Eurofound, 2014; Iannelli and Smyth, 2008; Lange et al, 2014). Qualitative research has focused on young people's agency as they navigate through these routes or pathways (see Evans and Furlong, 1997).

This paper seeks to clarify how young people's routes or pathways are constructed, how they are maintained, and how and when they change. It is argued that the construction is primarily downwards (backwards in terms of individuals' biographies), starting with employers' recruitment practices and preferences which govern recruitment to the education and training pathways from which employers seek young recruits. Researchers who wish to explain the links between origins, routes and eventual labour force destinations need to think backwards, starting in labour markets with employers' recruitment practices and preferences. Young people's agency propels individuals' lives forward (biographically upwards) but necessarily through opportunities that are pre-structured by other actors, most powerfully by employers. Young people's agency, variously influenced by advice and information from parents, teachers and peers, cannot help but consolidate the opportunity structures that have been formed from above, by other agentic actors, ultimately employers. The following passages show that once this is recognised, and only when this is recognised, it becomes possible to classify 
and explain different countries' education-to-work transition regimes, and to develop policies that will work in rebuilding young people's routes from education into their countries' labour forces.

Most detailed examples in the following passages are from the UK, the country that I know best, but all the arguments are claimed as valid internationally.

\section{Thinking Backwards}

In so far as studying a particular subject at a specific university is valued for the types of employment to which it is likely to lead, this value is determined by employers and is communicated through their recruitment practices and preferences. Needless to say, students may be attracted by a university's city location, its campus, intrinsic interest in a subject or course, possibly the university's reputation for quality teaching and maybe research, but here we are concerned only with employment prospects, and these are always likely to be among the attractions or inhibitors. One biographical step backwards, and it is the universities and courses and then jobs to which their pupils are known to progress that confer value on a secondary school though, needless to say, pupils' and parents' school preferences will also be influenced by other things including location and maybe religious ethos (if any). However, we know that many families will pay the full costs of education at private schools, and more will pay for additional coaching to complement the teaching at a state school, and households may make residential choices in order to live in the catchment area of a 'good' school. Here 'good' invariably means teaching that leads to the qualifications required by 'good' universities. Step back further and the attractions of an elementary or primary school will include whether its pupils meet the requirements for entry to a 'good' secondary school, and one might envisage competition for entry to nurseries that feed into 'good' kindergartens which feed into 'good' elementary schools. It is these processes, operating downwards in terms of the age groups that are affected, that create what are variously called career routes or pathways along which children then young people travel. These chains of causation start with employers. It is their definitions of employability that ultimately count. In addition to academic attainments and specialisations, employers may also take account of speech, personality, gender, religion and ethnicity (for examples see Jackson, 2009). Types of discrimination that are illegal can persist because they coincide with employability as defined by employers. It is employers' everyday common sense that counts most. Governments might declare that all universities and degrees have equal status, and may have accreditation procedures that certify this, but this will not necessarily affect employers' behaviour. They will continue to confine active recruitment to a small number of universities if this serves their purposes (see High Flyers Research, 2013; Wakeling and Savage, 2015). Why go to the trouble and expense of searching wider if past experience deems this unnecessary? Governments' (unconvincing) proposals to increase social mobility by cajoling employers to search wider (see Ashley et al, 2015; Milburn, 2012) are most likely to fall on deaf ears. Governments may declare that academic and vocational qualifications have equal status, but it is always employers whose evaluations are decisive.

At age 16,14 and sometimes earlier, young Europeans are likely to be offered a choice of, or they may be selected for entry into, either courses that are called academic or general, or others that are called technical, vocational or professional (Eurofound, 2014). Whether all the tracks have equal status or whether some are seen as better than others, depends ultimately on how they are treated by employers. If employers' preference for recruits who have taken academic or general education courses is sufficiently strong, then those who take other options are likely to be regarded as 'not good enough' and their routes may become residual. This is irrespective of the content and quality of the instruction, or government claims. Causation starts in youth labour markets, with employers' preferences and behaviour.

History always matters. All parents, teachers and employers have personal experience of the options that they faced and the courses that they took. When new courses and qualifications are introduced, elders are most likely to 'place' these in relation to what they know from personal experience. Until 1965 in England the only public examinations available for secondary school pupils were the GCEs that in 1951 replaced the School Certificates that had been introduced immediately following the First World War. Although they were very different qualifications - School Certificates were awarded to pupils who passed in a slate of subjects whereas GCEs were taken and passed or failed in single subjects - a clutch of the new (in the 1950s) GCEs was regarded as the equivalent of a former School Certificate.

Both examinations were designed to be taken only by pupils who attended grammar schools, which were academically selective. Other pupils finished their education without any generally recognised qualifications. However, in 1965 a Certificate of Secondary Education (CSE) was introduced, intended to be taken by the band of pupils who were considered not quite good enough to be entered for GCEs. A problem was that by age 16 some CSE candidates clearly were 'good enough', so a top grade CSE was said to be the equivalent of a basic GCE pass, but it was still a CSE, not a GCE. This is why in 1988 the qualifications were merged into the present-day GCSEs in which initially there were six grades, all nominally passes, A-F. However, in practice all parties recognised only grades A-C (the former GCE pass grades, which came to be regarded as equivalents of the earlier School Certificate) as genuine passes. Anything less was taken to mean 'fail'. From 2017 the A-F classification began to be replaced by 1-10. How were parents, pupils, teachers 
and employers to interpret these new grades? They really had no alternative except equivalents under the A-F scheme. So a 4 was treated as a basic $\mathrm{C}$ and 5 as a safe $\mathrm{C}$, and so forth. Thus the original School Certificate benchmark lives on.

In 1992 the UK allowed polytechnics and colleges of higher education to upgrade into universities, thereby creating a unitary higher education system. However, in terms of students' entry qualifications, measures of teaching quality, research culture and graduates' types of employment, the 'old' and 'new' universities are still distinct clusters. In contrast, the Russell Group, currently 24 of the old universities who regard themselves as 'above' the rest, are otherwise indistinguishable from other old universities in terms of the above indicators (Boliver, 2015). There is no historical base on which the Russell Group's claim can rest. However, in terms of graduates' jobs, Oxford, Cambridge and the top London universities (all among England's oldest universities) form a distinct cluster (Wakeling and Savage, 2015). This status is bestowed by employers, and maintained by the universities recruiting students who can be educated to match employability as defined by employers who recruit to elite jobs. A bottom cluster of new universities is also becoming distinct (Boliver, 2015) and if this cluster consolidates it will be graduate recruiters whose actions are decisive. This is how career pathways change. The impetus is from the economy and labour markets, communicated by firms' recruitment preferences and practices.

Attempts to enhance all young people's life chances by all-round boosts to levels of educational attainment always fail because the small number of top jobs does not change, nor the stratification of the remainder of the occupational structure. It is only upgrading in the occupational structure that can lead to an all-round improvement in young people's life chances, as happened In Western countries during the '30 glorious years' that followed the Second World War (see Roberts, 2011). Simply raising levels of educational attainment results only in the devaluation of all qualifications in terms of labour market returns.

\section{Situating Agency}

Young people have to be agentic in building their education-to-work transitions. Biographies are built upwards. Passivity is not an option. Young people are advised and informed by other agents - teachers, employers and parents - and the young people must decide whose advice to accept, if any. They are required to select from optional courses as they complete their education, to decide when to leave full-time education, and whether to apply for and accept places that are offered on any subsequent courses, training schemes and jobs. As youth life stage transitions have become longer, young people have been required to make more choices. Responsibility for outcomes, and indeed for entire youth biograhies, has thereby been privatised. Young people usually accept that they are responsible for the paths that their lives have taken, and not only accept but typically insist that they are in control of their own futures (see Devadason, 2007; Evans, 2002; Furlong and Cartmel, 2007). This true, but only to a limited extent.

Young people have different preferences - for study or something more practical, for example, as well as the importance they attach to remaining with peers and in the same locality - but amid all this they know that jobs and careers are arranged hierarchically, and that it is better to end up higher rather than lower. Like all humans, young people are rational actors in ways that their situations permit and require (Goldthorpe, 1998). Sub-cultural differences result in different socio-demographic groups - males and females, social class and ethnic groups - making different but equally rational choices from the same range of options. Young people's agency and rational choices are necessarily based on their own common sense. They are likely to feel able to see behind the labels. In the 1980s young people in Britain knew the difference between government-sponsored youth training schemes where they would be trained by an employer with a view to longer-term employment, schemes where they would be treated as temporary 'slave labour', and college- and community-based schemes which would just 'warehouse' them before returning the trainees to 'square one' (Lee et al, 1989; Raffe, 1987; Roberts and Parsell, 1992). Subsequently they have known the difference between government-sponsored apprenticeships which lead to prestige qualifications (which may be university degrees) and careers in management and the professions, from those which are really just 6-12 months of work experience (Kirby, 2015). They can tell the difference between universities because they know that they have different entry requirements.

Explaining how young people make their education-to-work transitions involves grasping the everyday common sense within which their rationality operates. However, the agents who construct young people's career routes or pathways include employers and all other actors who are responsible for pre-career recruitment to education and training pathways. Young people can choose only between options to which recruiters give them access. Thus their own agency inevitably propels individuals forward biographically along pathways that have been constructed 'backwards', and young people's own choices inevitably consolidate these pathways. 'Trajectories' is a superior metaphor to 'routes' or 'pathways' in so far as trajectories recognises both the push from young people and the pull from doors that have been opened only to individuals with the qualifications and other qualities that the gatekeepers deem relevant. Individual employers may feel that they are at the mercy of young people's choices. They may complain that they are unable to recruit bright 18 year olds who prefer several years of student life. Some employers are inevitably losers in a 'war for talent' in which too many 
graduate recruiters target top students from top universities (Brown and Hesketh, 2004). However, employers can change young people's preferences by offering higher pay or employment that is sandwiched between periods at university. Young people's agency is far less efficacious.

All parties act amid conditions of probabilities and degrees of certainty. Uncertainty increases for everyone in times of major changes in the numbers of students completing courses in academic/general upper secondary or higher education, or when institutions and qualifications with new names are introduced. Institutions' and credentials' reputations are the 'currencies' most commonly used by employers, students, and the parents and teachers who advise them. There is an interactive relationship. In times of major changes employers are likely to struggle as they try to locate the recruits that they have found satisfactory in the past. However, career routes or pathways and ultimately trajectories firm-up only when employers reach an (always imperfect) consensus, and they will always reach an understanding of the meaning of the new in terms of the older categories of institutions, courses and qualifications with which they have become familiar.

It is necessary to investigate both young people's and employers' preferences and behaviour and the agency of intermediate recruiters in order to explain fully education-to-work transitions, but most research attention has been devoted to young people's agency, and efforts to change outcomes for disadvantaged or lower-attaining (in education) groups have been most likely to target young people. This is despite the primacy of 'backward' processes in constructing career trajectories. Policy-makers who wish to change or redistribute outcomes need to follow the researchers who think backwards.

This is not to say that initiatives which make young people better informed about their options, which encourage them to plan ahead, and which boost their confidence, enterprise and resilience, can never affect outcomes. It is rather than any aggregate effects will depend on the opportunities that employers offer and how employers evaluate candidates who are better-informed, better planners, and who present themselves as confident and enterprising. Investing in human capital by retaining young people in education for longer will improve young people's life chances only if employers are able, willing or need to use this capital. New vocational options in education and training will improve the recipients' prospects only if employers rate the provisions as vocationally relevant and useful. The most efficacious decisions are made at 'the top', at the conclusion of education-to-work transitions, and the construction, maintenance and any changes in routes or pathways can be explained only by starting at the top then thinking backwards.

\section{Comparing Countries}

Anyone who undertakes international comparative research on education-to-work transitions immediately encounters qualifications and institutions with unfamiliar titles. The difficulties do not disappear with translation. There is usually no exact match in the investigator's home language.

The solution most commonly adopted is to divide institutions of education and training, and the qualifications to which their courses lead, into the two broad groups that were introduced earlier: the general and academic on the one side, and the technical, professional and vocational on the other. Courses and qualifications within each group can be arranged hierarchically according to which normally precede and follow each other in students' and trainees' careers, and the levels of employment to which the qualifications relate. Countries' lists of courses and qualifications can be given lengths according to the number of full-time equivalent years that are normally necessary to complete, and can be placed biographically by the typical ages at which young people enter and exit the programmes. A year spent in vocational education in one country can be deemed the equivalent to a year at the same level in a second country. A vocational qualification normally earned at age 18 in any country can be deemed the equivalent to a general or academic qualification normally earned at the same age. Currently the European Commission has an 8-level scheme into which all member (and other) states can place their courses and qualifications. This is intended to assist recruiters to different types and levels of education, training and employment in understanding the qualifications of migrants, thereby helping to create common European education and employment markets.

The problems are obvious. Academic and general education are not usually inter-changeable terms with identical meanings. The same applies to vocational, technical and professional. Some courses and qualifications can be both academic and vocational: university courses in medicine, architecture and law are examples. However, the insurmountable problem is that the meaning of any course, qualification or certified training can be understood only in relation to other parts of the 'transition regime' in the country where it is located. Scottish Highers, the qualifications normally used for university entry in Scotland, are not basically the same as the GCE A-levels that play the same role in the rest of the UK. None are basically the same as France's Baccalaureate which is now available in three versions. Germany's Abitur is different from them all.

This is not a problem for most students, parents, teachers and employers in any country. They need to understand only those parts of their own country's transition regime with which they engage. Their everyday knowledge, their common sense, needs to be sufficient, and this common sense will always be decisive. It is different when students, trainees or 
workers migrate across national borders, and when educational institutions and employers recruit internationally. Parents of secondary school age (and sometimes even younger) children may send these pupils to be educated in a second country. Why might they do this? Do they choose a second country on the basis of its PISA scores, the historically-built reputation of a country's schools, or a type of school, or just one particular school? Or is it the language of instruction or the country to which a family intends to return or where they wish to settle as migrants? For present purposes we do not need to answer these questions. We can simply note that answers are likely to differ from case to case, and the actors' everyday common sense will always be crucial. It is the same when higher education students spend a semester or year in a second country under the European Union's Erasmus programme. Are they attracted by the country, a particular university, the language of instruction, or subsequent employment possibilities? We know that the number of UK students using the Erasmus programme declined during the decades preceding the Brexit referendum in 2016. However, other flows of students out of the UK increased, some attracted by the lower fees in not-too-distant other European states, but others studying in the USA, Canada and Australia, all former British Empire countries and English-speaking. The students' typical motivation has been to earn qualifications at prestige universities having failed to gain entry to Oxford or Cambridge (Brooks and Waters, 2009). What attracts migrant workers to a destination country? There will be a similar range of answers, all in terms of the actors' everyday knowledge.

When educational institutions recruit from abroad they must decide on a case-by-case or country-by-country basis how to treat possible entrants' existing qualifications. It is the same when firms recruit labour from abroad. Here we know that salary expectations are likely to be among the considerations. Multi-national firms have the option of locating jobs in countries where labour (whether university-educated or completely unskilled) is better-qualified or cheaper than elsewhere, or preferably both. Globalisation thrusts countries into a 'Dutch auction', competing on the basis that their labour is superbly qualified, ready-trained and experienced, or (but preferably and) relatively cheap (see Brown et al, 2011).

In all cases, the behaviour of recruiters and the prospects of students and workers seeking to enter a country will depend on the character of the destination country's transition regime; its system of qualifications and employment opportunities whose meanings can be grasped only in relation to other parts of the same regime. There is now agreement among researchers who engage in comparative studies of education-to-work transitions that every country must ultimately be treated as a unique case (Raffe, 2014). At the same time, there is an ongoing search for a scheme that groups transition regimes into a limited number of different types.

\section{Types Of Transition Regimes}

The types in any typology of education-to-work regimes will be ideal-types: intentionally extreme, exaggerated and unrealistically coherent, and in these senses 'pure' representations of the types. In a good typology all the countries to be compared will approximate most closely to one of the ideal-types, and each country's best match will be a close fit. Esping-Andersen's typology of welfare regimes is an example (Esping-Andersen, 1990). This typology has been criticised frequently, usually for failing to represent countries accurately, but endures and remains widely used after a quarter of a century. Attempts have been made to map education-to-work transitions onto Esping-Andersen's typology, focusing on the experience of unemployment (Hammer, 2003) and students' experiences at university (Antonucci, 2016). However, a country's welfare regime, specifically its support for young people, is just one of many influences on how they make their transitions from education into working life. Antonucci (2016), in a comparison of England, Italy and Sweden, adds the influence of students' social class backgrounds in her analysis, but welfare and social class origins are just among many influences on UK students' experiences during then following university (see, for example, Bathmaker et al, 2013; Britton et al, 2016; Higher Education Careers Service Unit and Association of Graduate Careers Advisory Services, 2012; Higher Education Statistics Agency, 2014, Hussain et al, 2008; Purcell et al, 2012).

Attempts to purpose-build typologies of education-to-work transition regimes have usually begun by focusing 'horizontally' on mixtures of academic/general, and vocational/technical/professional routes through upper secondary education and vocational education and training, then glancing downwards at the origins of entrants to different mixtures, and upwards towards the young people's destinations (European Training Foundation, 2008; Raffe, 2008, 2014; Saar, 2005). None of these attempts at typology building can be declared successful. They do not pass the two tests outlined above. None of the typologies have become widely used, hence the continued resort by youth researchers to the Esping-Andersen typology.

Fortunately there is a solution, and it is amazingly simple. The solution is to begin by looking downwards or backwards. This means starting with the social organisation of a country's economy and labour markets then working back to the impact on different routes through education and training. This was recognised independently, but almost simultaneously, by two German sociologists, Markus Gangl (2001) and Marc Szydlik (2002). Gangl distinguished occupationalised and non-occupationalised labour markets. Szydlik distinguished those that were planned, flexibly coordinated and 
unregulated. Szydlik's example of a planned labour market was the former German Democratic Republic, a type that is still worth considering for some purposes, but which has now lapsed into history. As an example of an occupationalised labour market, Gangl chose the Federal Republic of Germany, the former West Germany and the present-day unified Germany. This was also Szydlik's choice of a flexibly coordinated labour market. Gangl's closet example of a non-occupationalised labour market was the USA, which was Szdlik's choice of one that was unregulated, and both used the UK as Europe's closest example. In what follows we will use Gangl's term 'occupationalised' and Szydlik's term for the 'unregulated' types.

In an ideal-typical fully occupationalised system, all young people are prepared for occupational careers whether they proceed along academic or vocational tracks. They exit occupationally qualified, then build careers within the occupations in which they can ascend by acquiring further skills, qualifications and experience. Individuals are able to move freely between employers, but always within their occupations in which they maintain their existing status. Careers hit serious obstacles when new technologies or economic change result in an occupation contracting or even disappearing. This happened to blacksmiths with the invention of the internal combustion engine, and more recently ICT has seriously reduced demand for secretarial skills such as shorthand and touch typing, and 'robots' equipped with 'artificial intelligence' are now replacing humans in many occupations in banking and other business and consumer services. If and when this happens, individuals may have to step back, train for new occupations and start afresh, though their existing skills and experience may lead to accelerated progress.

There are no real world examples of fully occupationalised regimes, and countries cannot simply decide to adopt this model. Establishing and maintaining an occupationalised system requires a high level of cooperation between 'social partners' - employers' associations, professions and trade unions, probably orchestrated by national, regional and local governments. Employers must regard it as their collective civic duty to offer routes through education and firm-based training leading to occupational careers for all young people who, in turn, must accept that they need to be prepared for then work to advance within their 'vocations'. Trade unions and professional bodies must cooperate in providing training and supervising the award of qualifications so that firms can employ labour with the skills and motivation that enable the businesses to compete successfully in national and international markets for their goods and services. If young people are to be 'sidetracked' into vocational education and training, school- and college-based vocational preparation must be bolted securely to firm-based training, and this must be the protected route into occupations which offer genuine career prospects. The 'sidetrack' must not only be a 'safety net' but also a genuine track which leads to a career (see Shavit and Muller, 2000). Young people with academic qualifications must not be allowed to 'step across' without 'stepping back' and progressing through the required vocational education and training. This enables the expansion of academic upper secondary and higher education to be contained (see Powell and Solga, 2011).

Even Germany's occupationalised transition regime is less pure than the ideal type. Some jobs are not occupationalised. These include shelf-stacking in supermarkets but also ICT-based occupations where employers find the occupationalised regime too slow and cumbersome to enable them to keep abreast of technological changes. Planning new routes through education and training, then waiting for the first cohorts to emerge full qualified, can take up to 10 years (see Kohler, 1999). Also, it has proved difficult to persuade young people in territories of the former German Democratic Republic to enter vocational routes, and employers have been reluctant to incur the expense of pre-career training (see Evans et al, 2000). Even so, the 'German model' is still admired throughout the world. Versions of this occupationalised regime are found in neighbouring countries (Belgium, the Netherlands, Luxembourg, Switzerland and Austria) which for historical reasons are all not only close to Germany geographically but also in terms of their economic cultures.

There are no actual pure unregulated regimes. The closest examples are the informal or unofficial sectors that spread rapidly throughout former communist countries in the 1990s (see Roberts, 2009), and which account for most young people's jobs in much of the present-day Global South (see Hansen, 2008). Otherwise there are always ages beneath which children cannot be legally employed, minimum pay and maximum hours laws, and health and safety regulations that employers observe. However, within these limits, in an unregulated regime employers hire and train according to their own requirements. Training tends to be in firm-specific skills, and know-how picked up informally is likely to be useful only within the firm. By gradually learning skills and acquiring knowledge of how a firm is run, employees can build ascending careers and become stereotypical organisation men and women (Whyte, 1957). Careers may suddenly collapse if a company closes or contracts or if it is merged into another business, leading to redundancies. When applying to other firms, job-seekers' existing skills and experience will be evaluated by the prospective employer. Each employer will decide how to rank whatever academic and vocational qualifications are offered by the applicants that it can attract. In an ideal-typical unregulated system, young people are not divided into different educational tracks, leading to different qualifications which lead to entry into different occupations, but follow a single educational track and drop out at different levels. In the USA some young people drop-out before completing secondary education. Others complete two-year college courses. Others progress to become graduates of top graduate schools at top universities as ranked by employers. 
Firms offering the best jobs, as evaluated by potential recruits, are able to hire 'the cream of the crop' (Katchadourian and Boli, 1994). Graduates with less prestigious qualifications trade down the labour market. Most high school students aim high, then most stumble (see Davidson, 2011). Those at the bottom of 'the queue' face the highest risks of unemployment. When students with the necessary ability cling on to the academic track, vocational courses become residual, a stigma rather than proof of competences. Apprenticeships, when introduced, do not earn the same recognition as in an occupationalised system (see Lehmann, 2008). Hence the perpetual debate in America about the situation of 'the forgotten half' (Rosenbaum, 2001).

Even within the limitations outlined above, the USA is a far from pure unregulated regime. All countries have occupationalised niches. Professions such as medicine, law and architecture are invariably occupationalised. In Estonia, Saar and her colleagues (2014) have found some occupationalised, and other business sectors that are unregulated in this way. Estonia's manufacturers tend to seek recruits with specific skills which beginners are most likely to acquire in vocational education and training. In contrast, Estonia's service sector employers tend to look for 'trainability' which is most likely to be judged by performances on academic or general education courses. The simple occupationalised/unregulated typology can cope with differences between and within countries. The point is that there are no further options. If a country or sector cannot or does not wish to occupationalise, its labour markets and youth transitions will become unregulated.

The experiences of former communist countries confirm this. The Soviet authorities developed their own version of Germany's occupationalised economy and youth training regime, and spread this throughout the Soviet republics, then after 1945 into the enlarged Soviet bloc. Its practices were passed on to the new independent states, most of which had to cope with massive economic restructuring and high levels of unemployment, especially among young people. Researchers found that vocational tracks continued to be protective, reducing risks of unemployment and increasing chances of quick transitions into first jobs (see Kogan and Unt, 2008; Kogan et al, 2011; Noelke et al, 2012). However, they also found that employers, seeking cost savings, were playing reduced roles on vocational tracks (Noelke and Horn, 2014). Simultaneously, the proportions of young people sticking on general or academic educational courses rose. An end result could be seen in some regions of Russia in the early-21 ${ }^{\text {st }}$ century where vocational routes had become 'zombie' provisions, still functioning, but dead in terms of trainees' career progression (Walker, 2007).

To summarise, comparing countries' transitions regimes is a complicated task because every country has a unique set of institutions, courses and qualifications, and a unique mixture of occupationalised and unregulated occupations, business sectors and firms. However, all these unique features and inter-country differences can be understood using the ideal-typical distinction between occupationalised and unregulated regimes. A firm, business sector, region or country may occupationalise if the necessary cooperation between 'social partners' can be achieved. Otherwise the default option is always non-regulation. So the outcomes of different academic and vocational routes are fixed 'above', in labour markets by employers' practices. Explanations require us to think backwards.

\section{The $21^{\text {st }}$ Century}

The education-to-work transition became a leading issue in youth research when, and because, pre-1939 rates of youth unemployment returned to Europe during and after the 1970s. Youth unemployment first became a problem in Western Europe's weaker economies, among their least qualified 'early' school-leavers aged 16-18. Gradually unemployment has spread from the under-18s to young people up to age 21, then 25 and then higher. It has spread from young people with no or low qualifications to those with intermediate qualifications and most recently to university graduates. It has become a serious problem in all European countries, old and new market economies, whatever their GDPs per capita and levels of labour productivity.

Many European cross-national research projects have considered whether national transition regimes that prepare young people for employment in vocational education and training (VET) offer better protection against risks of unemployment than those which retain higher proportions of 16-20 year olds in general or academic education. Generally, the results have favoured VET, but it is never possible to prove that their VET regimes are responsible for the countries' relatively low rates of youth unemployment. There is no message for all countries to act on. Countries do not really have a choice. If businesses, trade unions and professional associations wish to occupationalise their sectors of a labour market, they will do so. If not, non-regulation is the default option. There is no third way.

There have been some similar trends in education and youth labour markets throughout Western Europe. New technologies have always played a part in the decline of manufacturing employment and the traditional apprenticeships that these industries created. In Britain this trend began in the 1960s whereas in Germany demand for apprenticeships began to exceed the supply of places only in the 1990s (Kuda, 1998). Government efforts to boost firm-based training in Germany have led to a division between fully-qualifying and pre-qualifying apprenticeships (Protsch and Solga, 2016), similar to the difference between 'good' and 'bad' government-funded youth training schemes that was identified in 
Britain in the 1980s (Lee et al, 1989). More young people have been seeking and gaining admission to higher education in both Britain and Germany, which has led to clearer rankings among universities (Protsch and Solga, 2016). Throughout Europe there is trend towards young people's attainments being measured against a 'normal' academic track (Vogt, 2017). Recent research in Germany has found that short training courses yield the best monetary returns within the internal labour markets of the firms that mandate the training (Ehlert, 2017). Graduates who have been unable to obtain formerly commensurate jobs have stepped down the labour markets in all countries, typically at long-term costs to their earning prospects (Vobemer and Schuck, 2016). Risks of unemployment have thereby been passed down and remain highest among, though not confined to, the least qualified (Zwysen, 2016). The overall job deficit in Germany has been tackled since 2003 by permitting the creation of mini-jobs: low-paid ( $€ 450$ a month maximum in 2016) and short hours (maximum 15 per week) (see Dribbusch, 2010; Hillmert, 2010). The less regulated British economy has created swaths of low-paid, temporary, part-time and other forms of precarious employment (Standing, 2011). Yet basic cross-national differences persist. Germany's mini-jobs could only be created following agreement among the 'social partners', then legislation. In Britain employers simply decide to issue zero-hours contracts. Individuals need no qualifications or permission to set-up as self-employed cleaners, gardeners, decorators and so on. Despite the similar trends, there has been no clear convergence in Europe's education-to-work transition regimes (Lesnard et al, 2016). Germany's labour markets remain relatively occupationalised and regulated. Employees who are trained in sectors that remain outside the corporatist regime are confined within these sectors.

\section{Conclusions}

There are policy implications to draw from the foregoing analysis. First, restoring genuine full employment is a pre-condition for rebuilding transitions from education to work. Youth unemployment became a Europe-wide issue when full employment ceased to be the top priority in governments' economic policies after the 1970s. Governments decided to prioritise monetary inflation and to allow markets to set levels of employment and unemployment. Solutions to labour market imbalances were sought on the 'supply side'. Initially young people's skills and qualifications were said to be lagging behind technological change so governments invested in 'human capital'. When this failed to work it was decided that too many young people were acquiring the wrong types of human capital which was to be rectified by promoting vocational education and training. The results are now self-evident. Supply side policies are bankrupt. They now offer only normalising 'difficult transitions' and making young people responsible for developing their employability, resilience and perseverance.

Robots are not reducing the amount of work that is best performed by humans. Full employment can be restored by demand side management if governments operate 'soft' controls on labour supply and introduce 'hard' measures to distribute income so that work, currently undone, is converted into jobs for all job-seekers. Precarious jobs and technically superfluous education and training will then disappear quickly, as post-1945 did the dead-end jobs that blighted Western countries' youth labour markets pre-1939. There are obstacles. These include the technical aspects of controlling soft and hard labour supply and income distribution measures. There will also be resistance from groups that are benefitting from the status quo. Firms are able to trade profitably and have been taking rising proportions of GDP as returns to capital. A minority among professional and management staff can be rewarded generously, and some young people can be recruited into the high rising careers that lead to these jobs. Beneath them, a 'squeezed middle' may fear any change that could push them into a 'squashed bottom'.

Second, efforts to improve the prospects of disadvantaged groups via young people's agency will have limited success. In Britain there have been successive campaigns to widen horizons, unleash aspiration, and encouragement to aim higher. 'Employability' has been inserted into most education and training programmes. The results have been monitored, and have usually noted some 'positive outcomes'. The problem is that young people's agency will not create more jobs or change the character of the jobs that are available. At best, the agency of some young people shuffles unemployment onto others, and likewise with the more precarious jobs. Young people's agency is bound to consolidate opportunity structures that have already been built from above, by other agents, initially employers, then their pre-employment education and training gatekeepers. Young people's agency consolidates these structures because, as rational actors, even those who hope to change the world invariably decide, in the short-term, to build the best possible lives for themselves in the world as they find it. Critiques leading to policies that work must begin by thinking backwards, starting in the economy and labour market, and how employers decide who to recruit.

Third, there are no policies that will work with equal success in all countries. 'What works' in one place will rarely have identical outcomes elsewhere. Truly effective policies will be produced by national, regional and local governments which understand the histories of their own transition regimes and the meanings attached locally to their various forms and levels of education and training. Path dependence appears powerful. Practices adopted when countries first industrialised have tended to persist. They have been re-established very quickly after defeat in the world wars. Occupationalised niches have been formed in specific business sectors in parts of post-communist Poland that were once 
German or Austrian (see Klatt et al, 2015; Roberts and Szumlicz, 1995). Fortunately, occupationalised and unregulated regimes will perform equally successfully for employers and young people in conditions of full employment. Occupationalised VET systems will ideal-typically absorb all who wish to enter and will deliver the skills and qualifications required in different business sectors. Demand for labour in unregulated regimes will (again ideal-typically) absorb all young people in employment where they will be trained in the skills required by their employers. In rebuilding young people's education to work transitions, more 'subsidiarity' will work better everywhere than yet 'more Europe'.

\section{References}

Andres, L., \& Adamuti-Trache, M. (2008). 'Life course transitions, social class and gender: a 15-year perspective on the lives of Canadian young adults', Journal of Youth Studies, 11, 115-145. https://doi.org/10.1080/13676260701800753

Antonucci, L. (2016). Student Lives in Crisis: Deepening Inequality in Times of Austerity, Policy Press, Bristol. https://doi.org/10.2307/j.ctt1t89h62

Ashley, L., Duberley, J., Sommerlad, H., \& Scholarios, D. (2015). A Qualitative Evaluation of Non-Educational Barriers to the Elite Professions, Social Mobility and Child Poverty Commission, London.

Bathmaker, N. M., Ingram, N., \& Waller, R. (2013). 'Higher education, social class and the mobilisation of capitals: knowing and playing the game', British Journal of Sociology of Education, 34, 723-743. https://doi.org/10.1080/01425692.2013.816041

Boliver, V. (2015). 'Are there distinctive clusters of higher and lower status universities in the UK?' Oxford Review of Education, 41, 608-627. https://doi.org/10.1080/03054985.2015.1082905

Britton, J., Dearden, L., Shephard, N., \& Vignoles, A. (2016). How English Domiciled Graduate Earnings Vary with Gender, Institution Attended, Subject and Socioeconomic Background, Institution for Fiscal Studies Working Paper W16/06, Institute for Fiscal Studies, London.

Brooks, R., \& Waters, J. (2009). 'A second chance at "success": UK students and global circuits of higher education', Sociology, 43, 1085-1102. https://doi.org/10.1177/0038038509345713

Brown, P. \& Hesketh, A. (2004). The Mismanagement Of Talent: Employability and Jobs in the Knowledge Economy, Oxford University Press, Oxford. https://doi.org/10.1093/acprof:oso/9780199269532.001.0001

Brown, P., Lauder, H., \& Ashton, D. (2011). The Global Auction, Oxford University Press, Oxford.

Davidson, E. (2011). The Burdens of Aspiration: Schools, Youth and Success in the Divided Social Worlds of Silicon Valley, New York University Press, New York.

Devadason, R. (2007). 'Constructing coherence? Young adults' pursuit of meaning through multiple transitions between work, education and unemployment', Journal of Youth Studies, 10, 203-221.

https://doi.org/10.1080/13676260600983650

Dribbusch, H. (2010). Germany: Flexible Forms of Work: "Very Atypical" Contractual Arrangements, Eurofound, Luxembourg. https://www.eurofound.eu

Ehlert, M. (2017). 'Who benefits from training courses in Germany? Monetary returns to non-formal further education on a segmented labour market', European Sociological Review, 33, 436-448. https://doi.org/10.1093/esr/jcx042

Esping-Andersen, G. (1990). The Three Worlds of Welfare Capitalism, Princeton University Press, New Jersey.

Eurofound. (2014). Mapping Youth Transitions in Europe, Publications Office of the European Union, Luxembourg.

European Training Foundation. (2008). Transition from Education to Work in EU Neighbouring Countries, European Training Foundation, Turin.

Evans, K. (2002). 'Taking control of their lives? Agency in young adult transitions in England and the new Germany', Journal of Youth Studies, 5, 245-269. https://doi.org/10.1080/1367626022000005965

Evans, K., \& Furlong, A. (1997). 'Metaphors of youth transitions: niches, pathways, trajectories or navigations?' in Bynner J, Chisholm L and Furlong A, eds, Youth, Citizenship and Social Change in a European Context, Ashgate, Aldershot.

Evans, K., Behrens, M., \& Kaluza, J. (2000). Learning and Work in the Risk Society: Lessons for the Labour Markets of Europe from Eastern Germany, Macmillan, Basingstoke. https://doi.org/10.1057/9780230596023

Furlong, A., \& Cartmel, F. (2007). Young People and Social Change: New Perspectives, Open University Press, Maidenhead.

Gangl, M. (2001). 'European patterns of labour market entry: a dichotomy of occupationalized and non-occupationalized 
systems?' European Societies, 3, 471-494. https://doi.org/10.1080/14616690120112226

Goldthorpe, J. H. (1998). 'Rational action theory for sociology', British Journal of Sociology, 49, 167-192. https://doi.org/10.2307/591308

Hammer, T, ed. (2003). Youth Unemployment and Social exclusion in Europe: A Comparative Study, Policy Press, Bristol. https://doi.org/10.1332/policypress/9781861343680.001.0001

Hansen, K. T. (2008). 'Introduction: youth and the city', in Hansen K T with Dalsgaard A L, eds, Youth and the City in the Global South, Indiana University Press, Bloomington, 3-23.

High Flyers Research. (2013). The Graduate Market in 2013, High Flyers Research, London.

Higher Education Careers Service Unit and Association of Graduate Careers Advisory Services (2012). What Do Graduates Do? Higher Education Careers Service Unit, Manchester.

Higher Education Statistics Agency. (2014). DLHE: Introduction 2012/13, www.hesa.ac.uk. Accessed 11.08.2014

Hillmert, S. (2010). 'Traditional inequalities and new insecurities: long-term trends in the transition into the labor market in Germany', in Tremmel J C, ed, A Young Generation Under Pressure? Springer, Heidelberg, 57-76. https://doi.org/10.1007/978-3-642-03483-1_4

Hussain, I., McNally, S., \& Telhaj, S. (2008). University Quality and Graduate Wages in the UK, Discussion Paper, 99, Centre for Economic Performance, London School of Economics, London.

Iannelli, C., \& Smyth, E. (2008). 'Mapping gender and social background differences in education and youth transitions across Europe', Journal of Youth Studies, 11, 213-232. https://doi.org/10.1080/13676260701863421

Jackson, M. (2009). 'Disadvantaged through discrimination? The role of employers in social stratification', British Journal of Sociology, 60, 669-692. https://doi.org/10.1111/j.1468-4446.2009.01270.x

Katchadourian, H., \& Boli, J. (1994). Cream of the Crop: The Impact of Elite Education in the Decade After College, Basic Books, New York.

Kirby, P. (2015). Levels of Success: The Potential of UK Apprenticeships, Sutton Trust, London.

Klatt, M., Filip, P., \& Grzebyk, M. (2015). 'Understanding youth transition system in Poland through analysis of partnerships between vocational upper secondary schools and industry', Journal of Youth Studies, 18, 1186-1203.

Klein, M. (2016). 'Educational expansion, occupational closure and the relation between educational attainment and occupational prestige over time', Sociology, 50, 3-23. https://doi.org/10.1080/13676261.2015.1020938

Kogan, I., \& Unt, M. (2008). 'The role of vocational specificity of educational credentials for labour market entry in Estonia and |Slovenia', International Sociology, 23, 389-416. https://doi.org/10.1177/0268580908088898

Kogan, I., Noelke, C., \& Gebel, eds. (2011). Making the Transition: Education and Labour Market Entry in Central and Eastern Europe, Stanford University Press, Stanford.

Kohler, H-D. (1999). 'Adjustment problems between human resource strategies and public educational systems in Germany and Spain', paper presented to European Research Network on Transitions in Youth, Oslo.

Kuda, E. (1998). 'On the attractiveness of in-company training in the dual system of vocational education and training in Germany', TNTEE Publications, 1,1 .

Lange, M. de, Gesthuizen, M., \& Wolbers, M. H. J. (2014). 'Youth labour market integration across Europe: the impact of cyclical, structural and institutional characteristics', European Societies, 16, 194-212. https://doi.org/10.1080/14616696.2013.821621

Lee, D. J., Maarsden, D., Rickman, P., \& Duncombe, J. (1989). Scheming for Youth: a study of YTS in the Enterprise Culture, Open University Press, Milton Keynes.

Lehmann, W. (2005). '"I'm still; scrubbing the floors": experiencing youth apprenticeships in Canada and Germany', Work, Employment and Society, 19, 107-129. https://doi.org/10.1177/0950017005051298

Lesnard, L., Cousteaux, A-S., Chanvril, F., \& Hay, V. Le. (2016). 'Do transitions to adulthood converge in Europe? An optimal matching of work-family trajectories of men and women in 20 European countries', European Sociological Review, 32, 355-369. https://doi.org/10.1093/esr/jcw003

Milburn, A. (2012). Fair Access to Professional Careers, Cabinet Office, London.

Noelke, C., \& Horn, D. (2014). 'Social transformation and the transition from education to work in Hungary: a differences-within-differences approach', European Sociological Review, 30, 431-443. 
Noelke, C., Gebel, M., \& Kogan, I. (2012). 'Uniform inequalities: institutional differentiation and the transition from higher education to work in post-socialist Central and Eastern Europe', European Sociological Review, 28, 704-716. https://doi.org/10.1093/esr/jcs008

Powell, J. W. J., \& Solga, H. (2011). 'Why are higher education participation rates in Germany so low?' Journal of Education and Work, 24, 49-68. https://doi.org/10.1080/13639080.2010.534445

Protsch, P., \& Solga, H. (2016). ‘The social stratification of the German VET system', Journal of Education and Work, 29, 637-661. https://doi.org/10.1080/13639080.2015.1024643

Purcell, K., Elias, P., Atfield, G., Behle, H., Ellision, R., Luchinskaya, D., Snape, J., Conaghan, L., \& Tzanakow, C. (2012). Futuretrack Stage 4: Transitions into Employment, Further Study and Other Outcomes, Warwick Institute for Employment Research, Coventry.

Raffe, D. (1987). 'The Youth Training Scheme: an analysis of its strategy and development', British Journal of Education and Work, 1, 1-33. https://doi.org/10.1080/0269000870010102

Raffe, D. (2008). 'The concept of transition system', Journal of Education and Work, 21, 277-296. https://doi.org/10.1080/13639080802360952

Raffe, D. (2014). 'Explaining national differences in education-work transitions: twenty years of research on transition systems', European Societies, 16, 175-193. https://doi.org/10.1080/14616696.2013.821619

Roberts, K., \& Parsell, G. (1992). 'The stratification of Youth Training', British Journal of Education and Work, 5, 65-83. https://doi.org/10.1080/0269000920050104

Roberts, K., \& Szumlicz, T. (1995). 'Education and school-to-work transitions in post-communist Poland', British Journal of Education and Work, 54-74. https://doi.org/10.1080/0269000950080304

Roberts, K. (2009). Youth in Transition: Eastern Europe and the West, Palgrave Macmillan, Basingstoke. https://doi.org/10.1007/978-1-137-10359-8

Rosenbaum, J. (2001). Beyond College for All: Career Paths of the Forgotten Half, Sage Foundation, New York.

Saar, E. (2005). 'New entrants on the Estonian labour market: a comparison with EU countries', European Societies, 7 , 513-546. https://doi.org/10.1080/14616690500194092

Saar, E., Unt, M., Helemae, J., Oras, K., \& That, K. (2014). 'What is the role of education in the recruitment process? Employers' practices and the experiences of graduates from tertiary institutions in Estonia', Journal of Education and Work, 27, 475-495. https://doi.org/10.1080/13639080.2013.781268

Shavit, Y., \& Muller, W. (2000). 'Vocational education: where diversion and where safety net?' European Societies, 2, 29-50. https://doi.org/10.1080/146166900360710

Standing, G. (2011). The Precariat: The New Dangerous Class, Bloomsbury Academic, London.

Szydlik, M. (2002). 'Vocational education and labour markets in deregulated, flexibly coordinated and planned societies', European Societies, 4, 79-105. https://doi.org/10.1080/14616690220131008

Vobemer, J., \& Schuck, B. (2016). 'Better overeducated than unemployed? The short- and long-term effects of an overeducated labour market re-entry', European Sociological Review, 32, 251-265. https://doi.org/10.1093/esr/jcv093

Vogt, K. C. (2017). ‘Age norms and early school-leaving', European Societies. https://doi.org/10.1080/14616696.2017.1358391

Wakeling, P., \& Savage, M. (2015). 'Entry into elite positions and the stratification of higher education in Britain', Sociological Review, 63, 290-320. https://doi.org/10.1111/1467-954X.12284

Walker, C. (2007). 'Navigating a "zombie" system: youth transitions from vocational education in post-Soviet Russia', International Journal of Lifelong Education, 26, 513-531. https://doi.org/10.1080/02601370701559607

Whyte, W. H. (1957). The Organization Man, Anchor Books, New York.

Zwysen, W. (2016). 'Crowding out of disadvantaged young adults in Germany: background matters depending on local labour market', European Sociological Review, 32, 662-674. https://doi.org/10.1093/esr/jcw023

Ken Roberts is Professor of Sociology at the University of Liverpool. His books include Surviving Post-Communism: Young People in the Former Soviet Union (2000). Youth in Transition: Eastern Europe and in the West (2009), Class in Contemporary Britain (2011), Sociology: An Introduction (2012), The Business of Leisure (2016), and Social Theory, Sport, Leisure (2016). 


\section{Copyrights}

Copyright for this article is retained by the author(s), with first publication rights granted to the journal.

This is an open-access article distributed under the terms and conditions of the Creative Commons Attribution license (http://creativecommons.org/licenses/by/4.0/). 